\title{
Study on the Planning of Personal Income Tax Salaried College Staff
}

\author{
Wenyuan Chen \\ Jiangsu Vocational Institute of Commerce, Nanjing, Jiangsu, 211168
}

Keywords: colleges and universities; payroll; tax; planning

\begin{abstract}
The so-called colleges payroll tax planning refers to the foundation not in violation of state tax laws, all sorts of clever planning and arrangements are carried out for the college staff to maximize the benefits and reduce the tax fee. College payroll tax planning must adhere to legitimacy, target, and overall principles. College payroll tax planning methods are fully based on Preference Act, the balance wage law, and subsidy law invoice to avoid blind law.
\end{abstract}

\section{Introduction}

The so-called personal income tax planning for colleges payroll refers to all kinds of clever plans and arrangements for reducing tax burdens to maximize the interests of university staff. Colleges should pay attention to the tax planning of salaries, help faculty and staff, make full use of preferential tax policies, and reduce tax burdens within a legal scope. Individual income tax revenue planning in colleges should adhere to the principle of proper planning and avoid misunderstandings.

\section{Main Misunderstandings in the Tax Planning of Personal Income Tax in Colleges}

The so-called misinterpretation of the tax law refers to the misunderstanding caused by the misunderstanding of the meaning of the national tax law by college taxpayers. For example, some professors participate in the senior professional title review and refuse to sign and collect the review fee. The reason is that they receive a few hundred yuan, and the tax rate is increased by one file, which is even more uneconomical. The taxpayer here misunderstood the progressive tax rate as a full progressive tax rate. For example: a professor's monthly salary of 8,000 yuan, tax payable amount $=($ work pay -3500) $\mathrm{x}$ applicable tax rate - quick calculation deduction $=(8000-3500) \mathrm{x}$ $10 \%-105=345$ (yuan); assuming 200 yuan in assessment fees, Tax payable $=(8200-3500) \times 20 \%-$ $555=385$ (yuan). It can be seen that the professor has received more than 200 yuan. Although the tax rate has increased from $10 \%$ to $20 \%$, he only paid 40 yuan in taxes and earned 160 yuan. The professor thinks that it is uneconomical to mispay 4700 yuan by $20 \%$. Actually, over 200 yuan is taxed at 20\%, within 1500 yuan, tax is still payable at 3\%, and between 1,500 yuan and 4,500 yuan is still at $10 . \%$ pay taxes. This is an individual taxation taxation tax law, it should popularize the tax law, so that taxpayers clearly pay taxes.

The so-called "correct tax avoidance mistake" refers to the fact that the leaders and financial personnel of colleges in order to reduce tax exemption for taxpayers in this school, and convert part of the salary into fees, is regarded as a misunderstanding of reasonable tax avoidance. It is usually university leaders and financial staff who blur the boundaries between tax planning and tax avoidance. Such so-called reasonable tax avoidance has characteristics such as planning, low risk, high profitability, pseudo publicity, and scale. For example, reimbursement of the Academy's research awards in the form of invoices; or privileged lecture fees, invigilation fees, overtime pay, etc. in the name of travel expenses, telephone bills, etc. are all products of such so-called reasonable tax avoidance. The new tax law regulation clearly stipulates income from wages and salaries: "refers to wages, salaries, bonuses, year-end salary increases, labor dividends, allowances, subsidies, and other income related to employment or employment that an individual obtains from employment or employment". It also pointed out that "wage and salary income are subject to excessive progressive tax rates, with a tax rate of $3 \%$ to $45 \%$." According to the tax law, the Academy's scientific research incentives should be taxed and converted into fees, so there is no 
need to pay taxes. This is intentional tax avoidance; taking lecture fees, invigilation fees, and overtime pay in the name of travel expenses, telephone bills, etc., are all tax evasion and tax evasion actions. This kind of so-called reasonable tax avoidance not only reduces the country's tax revenue, but also creates new inequities, putting the taxpayers according to law at a competitive disadvantage.

\section{The Principle of Personal Income Tax Revenue Planning in College}

The principle of legitimacy refers to the taxation plan for individual income taxation of colleges. When choosing a plan to reduce tax burdens and maximize profits, it must insist that it does not violate the fundamental principles of state laws and tax laws and regulations. The personal income tax revenue planning for colleges is carried out within the scope of the national specific regulations. It is not tax evasion. The difference between them is that the former is legal and the latter is illegal. In other words, whether or not legality is the basis for measuring tax planning and tax evasion. The premise of tax planning for individual income tax in colleges is legal, and all illegal activities cannot be called tax planning. The tax planners for personal income tax in colleges only have the connotation of tax evasion, and have deep processing capacity for taxation policies. Only in this way can tax planning be conducted effectively. Otherwise, tax planning will become a disguised form of tax evasion and tax avoidance.

The so-called advancement principle refers to the tax planners who pay personal income tax in colleges must have a long-term vision, with a keen sense of foresight, in order to be far-sighted, grasp the macro, understand the forefront, adhere to the principle of pre-planning. Tax planning is a top-level integrated high-intelligence, high-emotional financial management practice. It is a guiding role played by managers and planners in the rational and legal application of tax laws. Through the overall arrangement of the whole process of college education activities in advance, they achieved the goal of reducing the tax burden. Therefore, they were ahead of the curve. If you neglect the premeditated plan, tax, tax, and tax rates are a foregone conclusion, making it difficult to make up for it later. To truly adhere to the principle of advancement, tax planners must have extensive contacts and rich knowledge. They must pay attention to the subtle changes in the taxation field through various media channels, and make in-depth studies to get a thorough understanding of the macro, meso, and microscopic perspectives. On the chest.

The so-called target principle means that tax planning should use the best plan to reduce the personal tax burden on university staff and teachers, so as to maximize the benefits. The objective principle requires that tax planning be the same as other tasks and that there should be a goal in advance. Before planning, the planner must understand the applicable tax rate, the tax burden of the individual income tax, the salary status of the specific person, etc., and on this basis, consider the possibility of planning and set the objectives to be achieved. If a scheme can reduce the tax burden of a faculty member somewhere in a month, but it may reduce overall profit, it is not desirable. For example, a professor who is part-time outside the school has a 9,000 RMB extracurricular tuition for a month, and the tax planning for a part-time college is calculated based on the salaried wages. Withholding tax is 545 yuan [(9000-3500) $\times 20 \%-555=545$ (yuan)]. On a monthly basis, the tax planning of a part-time college succeeded in reducing the tax burden for the professor by 895 yuan [If calculated on the basis of the service compensation, the tax should be paid $9000 \mathrm{x}(1-20 \%) \mathrm{x}$ $20 \%=1440$ yuan, 1440-545 = 895 yuan]. However, on the whole, the salary of the professor's school is also 9,000 yuan this month. If the two schools total 18,000 yuan, which exceeds 9,000 yuan, they must pay tax at the rate of 25\%, and they must pay 2620 yuan [(18000-3500) x 25\% $1005=2620$ (yuan)]; if the tax planning for a part-time school does not count according to the salary, the change is calculated according to the service remuneration, as long as the tax is paid at the $20 \%$ tax rate, and the two places are combined and paid a total of 1985 yuan [(9000-3500) $\times$ $20 \%-555+1440=1985$ (Yuan)]. That is to say, on the whole, the tax planning for a part-time school is calculated according to the labor compensation. For the professor, the monthly tax rate is $2620-1985=635$ (yuan). Therefore, if we stick to the principle of goal, we should abandon the small profits with a reduced tax burden and seek greater profits from the reduction of the overall tax 
burden, so as to truly maximize the benefits of the professor.

The so-called global principle means that tax planners must be based on the overall situation and have a holistic mind when it comes to tax planning for personal income taxation in colleges. They insist on the overall coordination and harmonization of local taxation departments, colleges, and individuals, and fully weigh the pros and cons. Taxation is an overall task, and the state also formulates a number of preferential tax policies when formulating tax laws. For example, a special government grant granted by a professor to the State Council is one of the preferential tax policies. Tax planners must not only consider the tax rate of personal income tax on wages, but also consider various preferential tax policies; they must not only be good at using national laws and tax laws and regulations, but also consider the characteristics of incomplete tax laws. They should promptly contact the local tax authorities when faced with vague problems. Communicate and coordinate, increase the factors of successful tax planning; not only need to see the reduction of individual tax burdens, exemption from payment, but also see the overall reduction of tax burden, it should be compared aspect to side, do not lose sight of each other; not only from the financial management point of view to consider simple The operability must also take into account the intricacies of the individual staff of the faculty and staff, non-replication, etc. Such as: a lecturer outside the school as a lecturer, the school salary income 5000 yuan per month, 3,000 yuan per month outside school, if students apply rigidly, according to the above example of a professor planning, extracurricular and class according to the calculation of labor remuneration, it would greatly increase the tax burden. We can compare it. The first is that the extracurricular school class is calculated according to the service remuneration, and the monthly tax payable is 485 yuan $[(5000-3500) \times 3 \%+(3000-800) \times$ $20 \%=485$ (yuan)]; The monthly tax payable is 345 yuan $[(5000+3000-3500) \times 10 \%-105=345$ (yuan)]. Obviously, the second plan of the lecturer is 140 yuan more than the first schedule of tax savings.

In addition, there are long-term principles, basic principles, timing principles, economic principles, and timeliness principles. These are not repeated here. In short, tax planning is a very professional job. It should be legally reasonable and reasonable. It should not be illegal because of the reduction of tax burdens. Do not use shells to bombard or lose watermelon.

\section{Method of Personal Income Tax Revenue Planning for College}

The personal income tax income tax of colleges in China, from September 1, 2011 onwards, is a seven-level progressive tax rate, according to national laws, tax regulations and tax formula: taxable amount $=$ (payroll $-3,500$ yuan) $\mathrm{x}$ applicable tax rate - deductible The number of taxation methods for personal income tax in colleges is mainly the following:

Full discount law

The so-called full-concession law refers to tax planning methods that maximize the use of state tax incentives to lower the tax base. The state provides basic old-age insurance, basic medical insurance, unemployment insurance, provident fund, provincial and ministerial government grants, provincial and ministerial or higher awards, state housing allowances, childcare subsidies, one-child fees, and travel grants, and does not impose personal income tax. Many of these tax-exempt items are flexible in terms of their contributions. The upper and lower limits are stipulated and can be fully utilized to maximize profits. For example, the 2015 provincial housing authority's base for housing provident fund deposits, "the maximum limit is no more than 18,200 yuan, the minimum limit is still 1,630 yuan," then the difference between paying the housing accumulation fund by the upper limit or the lower limit is 16570 yuan per year. Of course, the housing provident fund can be paid according to the ceiling. better. However, not all are paid well according to the upper limit. For example, unemployment insurance, colleges belong to public institutions, and generally do not lose their jobs. It seems that it is more appropriate to pay on line. In short, specific analysis should be made on specific conditions. It is also possible to encourage particularly good teachers to strive for provincial and ministerial government subsidies and encourage teachers to strive for provincial or ministerial awards.

The so-called "Balanced Salary Law" refers to the method of tax planning that will lead to the 
fluctuations in wages and salaries of college teachers, and is based on a 12-month average assessment of taxation. Balancing the salary law will help college teachers reduce their tax burden. College teachers have more classes in the first half of the year, and fewer or even no classes in the second half of the year. In the first half of the year, there are fewer classes and more classes in the second half of the year; some have more classes in the first half of the semester, fewer classes in the second half of the semester, and some in the first half of the semester. Less, more classes in the second half of the semester. In this way, the rise and fall of each month will result in a high-paying month. Teachers' tax burden will be heavy. In the month of low income, the tax burden on teachers will be light. Once the monthly salary income is formed, the tax burden cannot be changed, and how much cannot be supplemented, virtually increasing the tax burden on teachers. If tax planning is carried out, according to the balanced wage law, the tax burden will be greatly reduced. The Balanced Workmanship Law is suitable for teachers whose tutors are ups and downs. The application of the Balanced Salary Law to specific individuals not only saves tax, but also facilitates taxation and tax payment for financial staff. The personal tax paid by the financial staff for the first 11 months is the same. In the last month, the number of hours can be increased according to the number of hours. Therefore, the financial staff has 10 months without taxation in the first year. There are hundreds of schools in the school. Thousands of teachers save a lot of time. The balance of salary law is more suitable for some private vocational colleges. Public vocational colleges should combine year-end one-time bonuses with comprehensive consideration and make full use of the year-end one-time bonus incentives.

The so-called subsidy invoice method means that the subsidy such as traffic, telephone, and newspapers and newspapers subsidies are actually used in these projects.

The method of verification of interim invoices reduces the method of planning the tax burden. Such as real-name telephone bill invoices, purchase invoices and so on. For example, an associate professor's salary is 8,500 yuan, of which 700 yuan is for transportation expenses, 300 yuan for telephone expenses, and 300 yuan for book and newspaper expenses. The associate professor actually used the transportation fee of 500 yuan, the telephone fee of 200 yuan, and the newspaper and book fee of 200 yuan, and wrote off the invoice in the form of an invoice (invoice must be real-name system, or provide physical evidence, human certificate). With the subsidy invoice method, the professor should pay 305 yuan [(8500-500-200 -200-3500) x 10\%-105 = 305 (yuan)]. Using the usual algorithm, the professor should pay 445 yuan [(8500-3500) $\times 20 \%-555=445$ (yuan)]. The subsidy invoice method uses less than 140 yuan per month. Here we must pay attention to: If you do not use the actual cost of invoices to write off, and deliberately part of the wage invoice, is the aforementioned "rational tax avoidance mistakes." The difference lies in seeking truth from facts or falsifying.

The so-called avoidance blind area law refers to the method of tax planning that promotes that college staff's year-end awards do not fall into the "invalid range" of multiple awards and less income. Since the quick deductions suitable for the payroll tax rate are not entirely suitable for the calculation of the year-end bonus tax, there are six blind spots (invalid intervals) for each tax. The year-end prizes for university staff are not high, and generally they do not fall into the first 3 blind spots. The first three blind spots were 18001 to 19283.33 yuan, 54001 to 60187.50 yuan, and 108001 to 114600 yuan respectively. If the year-end bonus falls on these three blind spots, the bonus will be a little more and the income will be even less. Assume that Professor Wang and Professor Peng's monthly salary is higher than 3,500 yuan, the year-end bonuses of the two are 54,000 yuan and 60,000 yuan respectively, Professor Wang is $54000 \div 12=4,500$ yuan, and the corresponding tax rate and quick deduction are $10 \%$ and 105 yuan. The tax is 5295 yuan [ $54000 \times$ $10 \%-105=5295$ (yuan) $]$ and the tax is 48,705 yuan.

Professor Peng: $60000 \div 12=5,000$ yuan, the corresponding tax rate, quick deductible number: 20\%, 555, taxable 11445 yuan [60000 × 20\% -555 = 11445 (yuan)], after-tax income 48,055 yuan. Professor Wang's year-end prize is 6,000 yuan lower than Professor Peng, and his after-tax income is 150 yuan higher than Professor Peng. Using the method of avoiding blind spots, first, financial personnel and leaders should be controlled outside the blind spot when setting year-end bonuses; 
second, individual staff and teachers can also donate the part that falls in the blind spot, even if they have to work harder, Helps alleviate poverty.

In addition, the payroll tax planning for college teaching staff should also pay attention to the overall balance. It should be based on individual adjustment and concrete analysis of specific conditions. At the same time, we must also pay attention to changes in taxation policies, earnestly understand the connotation of tax regulations, and accurately grasp the sense of proportionality in tax planning. Starting from the development of the college, the value of education, and the overall interests, the risk prevention will increase the chance of successful tax planning.

\section{References}

[1] Xiao Xinhua. Study on the Individual Income Tax Planning of University Teachers Based on the Background of Performance-Based Wage Reform [J]. Journal of Hubei Radio \& TV University, 2014, (10).

[2] Dou Tong. Individual Income Tax Planning for Wage and Salary Income [J]. Tax Collection, 2016, (2). 